Planning, Development, and Change:

A Bibliography on Development Administration 



\title{
PLANNING, DEVELOPMENT, AND ChANGE
}

A Bibliography on Development Administration

\author{
Compiled by \\ Garth N. Jones \\ Shaukat Ali \\ Richard Barber \\ James F. Chambers
}


Copyright (c) 1970 by East-West Center Press University of Hawaii

Al1 rights reserved

International Standard Book Number: 0-8248-0099-0

Library of Congress Catalog Card Number: 77-138823

Printed in the United States of America

First edition 